спрямувати на розробку педагогічних умов ефективного формування професійно-педагогічної відповідальності майбутнього вчителя початкової школи.

\section{СПИСОК ВИКОРИСТАНОЇ ЛІТЕРАТУРИ}

1. Андрущенко В. Сучасна соціальна філософія / В. Андрущенко, М. Михальченко. - К. : Генеза, 1993. T. $1 .-246 \mathrm{c}$.

2. Бернштейн Д. Правовая ответственность как вид социальной ответственности и пути ее обеспечения / Д. Бернштейн. - Ташкент: Фан, 1989. - 150 с.

3. Бех І. Д. Психолого-педагогічні умови виховання в молоді громадянськості / I. Д. Бех // Громадянське виховання молоді в умовах трансформації суспільства. - Черкаси, 1998. - С. 3-6.

4. Великий тлумачний словник сучасної української мови / уклад. і голов. ред. В.Т. Бусел. - Київ ; Ірпінь : Перун, 2004. - 1440 с.

5. Етимологічний словник української мови : в 7 т. - Київ : Наукова думка, 1982. - Т. 1. - 631 с.

6. Макаренко А. С. Педагогічні твори : у 8 т./ А. С. Макаренко. - М. : Педагогіка, 1983. - Т. 1. - 67 с.

7. Муздыбаев К. Психология ответственности / К. Муздыбаев. - Л. : Наука, 1983. - 240 с.

8. Сафин В. Психология соопределения личности / В. Сафин. - Свердловск, 1986. - 142 с.
9. Словарь по этике / ред. И. С. Кон. - М. : Политиздат, 1983. - Изд. 5. - 445 с.

10. Словарь-справочник по психологической диагностике / Л. Бурлачук, С. Морозов. - К. : Наукова думка, 1989. - 200 с.

11. Сухомлинський В. Серце віддаю дітям. Народження громадянина. Листи до сина / В. Сухомлинський // Вибрані твори: в 5 т. - К. : Рад. школа, 1977. - Т. 3. -670 c.

12. Тульчинский Т. Л. Разум, воля, успех: о философии поступка / Т. Л Тульчинский. - Л. : Изд. ЛГУ, 1990. - 119 с.

13. Юридичний словник / за ред. В. Г. Гончаренка. - К. : Форум, 2005. -473 с.

14. Філософський енциклопедичний словник / В. І. Шинкарук, Л. В. Озадовська, Н. П. Поліщук. - Київ : Абрис, 2002. - 742 с.

15. Dictionnaire français [Electronic resource]. URL: http://www.toupie.org/Dictionnaire/Responsabilite.htm (дата звернення: 03.05.2019).

16. Oxford English Dictionary. The word «responsibility» [Electronic resource]. URL: http://www.oed.com/ view/Entry/163862?redirectedFrom=responsibility\#eid (дата звернення: 15.05.2019).

Дата надходження до редакиії: 25.06.2019 р.
Надія МЕЛЬНИК, кандидатка педагогічних наук, доцентка кафедри філософії, економіки та менеджменту освіти, проректорка із науково-методичної роботи Рівненського ОІППО

\title{
МЕТОДИЧНІ ІДЕЇ ПЕДАГОГІЧНОЇ СИСТЕМИ ВАСИЛЯ СУХОМЛИНСЬКОГО В КОНТЕКСТІ НОВОЇ УКРАЇНСЬКОЇ ШКОЛИ
}

У статті описано основні ідеї педагогічної системи В. О. Сухомлинського, впровадження яких матиме фундаментальне значення для становлення $i$ розбудови Нової украӥнської школи, реалізачіі основних ключових компонентів ї̈ формули. Особливу увагу акиентовано на важливості розвитку професійної компетентності сучасного педагога, формуванні його авторитету, високих особистих якостей. Доведено, щзо використання педагогічної спадшини Василя Сухомлинського в освітньому проиесі закладів освіти позитивно вплине на формування інновачійної, патріотично налаштованої особистості, здатної до сприйняття і творення продуктивних змін і нововведень у різних галузях економіки $і$ суспільного життя краӥни.

Ключові слова: педагогіка партнерства, дитиноичентризм, иінності, компетентності, особистісна орієнтація освіти.
В статье описаны основные идеи педагогической системы В. А. Сухомлинского, внедрение которых будет иметь фундаментальное значение для становления $u$ развития Новой украинской школь, реализации основных ключевых компонентов ее формуль. Особое внимание акцентировано на важности развития профессиональной компетентности современного педагога, формировании его авторитета, высоких личных качеств. Доказано, что использование педагогического наследия Василия Сухомлинского в образовательном проиессе учебных заведений положительно повлияет на формирование инновационной, патриотически настроенной личности, способной к восприятию и созданию производительных изменений и нововведений в различных отраслях экономики и общественной жизни страны.

Ключевые слова: педагогика партнерства, ребенкоцентризм, иенности, компетентности, личностная ориентация образования. 
The article deals with basic ideas of the pedagogical system of $V$. Sukhomlynsky, which introduction will be fundamental for the formation and development of the New Ukrainian School, the implementation of the main key components of its formula.

Particular attention paid to the importance of developing the professional competence of a modern teacher, formation of its authority and high personal qualities. It has been proved that the use of V. Sukhomlinsky's pedagogical heritage in the educational process of educational institutions has a positive effect on the formation of innovative, patriotic personality, capable of perceiving and creating productive changes and innovations in various sectors of the economy and public life of the country.

In conditions of rebuilding modern national school in Ukraine, educators and scholars must increasingly direct their views to the creative endeavors of the prominent humanist educator V. Sukhomlynsky, as his multifaceted scientific and pedagogical works address the major problems of modern pedagogy and promote innovational development of a New Ukrainian School.

The particular importance in New Ukrainian School acquires methodological ideas of the pedagogical system of V. Sukhomlynsky, which are based on the school's deep partnership as a public educational system and pedagogical mastery of the teacher, aimed at developing creative personality and creativity.

Ideas of Sukhomlinsky's will undoubtedly be established in the pedagogy and philosophy of modern education will become the basis of the reform processes of the educational sphere and will help to overcome challenges of the national secondary education.

Key words: partnership pedagogy, child-centeredness, values, competencies, personal orientation of education.

Постановка проблеми. Сьогодні українське суспільство знаходиться на порозі змін, прагне посісти чільне місце серед європейських країн. Особливі зміни відбуваються і в українському освітньому просторі. Нова українська школа - це довгострокова реформа, спрямована на оновлення загальної середньої освіти як основної ланки безперервної освіти, що забезпечує формування учня як особистості, закладає фундамент для успішної самореалізації впродовж життя. Упродовж останніх десятиліть істотної трансформації зазнала іiі цільова спрямованість, організація навчального процесу, дидактико-методичне забезпечення, підходи до оцінювання освітніх результатів у напрямі посилення особистісної орієнтації освіти, ії розвивального, компетентнісного, демократичного характеpy [5]. Проте низка зовнішніх і внутрішніх чинників зумовили потребу ще багатьох інших змін у системі загальної середньої освіти, насамперед в оновленні мети, змісту та організації навчання відповідно до європейських освітніх тенденцій, запровадженні нових компетентнісно орієнтованих освітніх стандартів. Головне завдання реформи - це оновлення змісту освіти 3 переходом на компетентнісне навчання, формування конкурентоздатного випускника, підготовка вчителя та створення нового освітнього середовища для підвищення якості освіти.

Особливого змістового значення в Новій українській школі набувають методичні ідеї педагогічної системи Василя Сухомлинського, які можна назвати поглядом у майбутнє, оскільки вони засновані на глибинному партнерстві школи як суспільної освітньої системи і педагогічної майстерності вчителя, спрямованої на формування творчої особистості, патріота та інноватора.

Аналіз наукових досліджень і публікацій. Вивченню різних аспектів літературної та наукової спадщини В. Сухомлинського присвячено значну кількість наукових досліджень. Основні аспекти теорії педагогічної культури та напрями діяльності видатного педагога щодо становлення та вдосконалення системи роботи з розвитку педагогічної майстерності вчителя досліджували такі вчені, як М. Антонець, І. Баранюк, I. Бех, О. Білюк, Л. Бондар, Г. Бондаренко, С. Денисюк, Н. Калініченко, В. Кравець, А. Луцюк, Н. Ничкало, О. Околович, О. Савченко, Г. Сагач, Т Саєнко, О. Сухомлинська та ін. У їхніх наукових працях розглянуті також гуманістичні ідеї вченого, методологічні принципи виховання, проблеми дидактики тощо. Певні аспекти педагогічної діяльності Василя Сухомлинського розглядалися на монографічному рівні М. Ярмаченком, М. Красовицьким, М. Сметанським, І. Зязюном, Г. Калмиковою та ін. Такі вчені, як М. Богуславський, Б. Кваша, М. Мухін, В. Риндак, А. Розенберг, О. Сухомлинська, у своїх працях проаналізували основні складові педагогічної системи В. Сухомлинського, описали етапи їх становлення й розвитку.

Питання розвитку професійної компетентності сучасного педагога в умовах модернізації системи освіти, формування конкурентоздатного фахівця розкрито в працях таких науковців, як В. Олійник, Н. Любченко, Н. Білик, В. Бондар, Л. Даниленко, Г. Сльникова, О. Зайченко, Л. Колосова, Н. Клокар, В. Луговий, В. Маслов, Н. Побірченко, Л. Покроєва, Н. Протасова, В. Пуцов, С. Сисоєва, Т. Сорочан, А. Фасоля та ін.

В умовах розбудови сучасної національної школи в Україні освітяни та вчені мають усе більше скеровувати свої погляди до творчого доробку видатного педагога-гуманіста В. Сухомлинського, адже його багатоаспектні науково-педагогічні праці стосуються найважливіших проблем сучасної педагогіки та сприяють інноваційному розвитку Нової української школи.

Мета статті - розкрити основні аспекти застосування методичних ідей педагогічної системи Василя Сухомлинського в сучасному освітньому просторі, значущість використання педагогічного досвіду педагога-новатора для реалізації ключових компонентів формули Нової української школи та визначити вплив ідей видатного вченого на формування освіченого і всебічно розвиненого учня - патріота і громадянина, здатного до інновацій, та розвиток професійної компетентності педагогічних працівників.

Виклад основного матеріалу. Сучасну педагогіку неможливо уявити без надбань класиків педагогічної думки. Працюючи в умовах становлення Нової української школи, і керівники закладів освіти, i вчителі, і батьки все частіше звертаються до мудрих, глибинних джерел педагогічної спадщини таких видатних педагогів, як К. Ушинський, О. Духнович, А. Макаренко, В. Сухомлинський та ін.

Знаковою постаттю серед видатних педагогів минулого є Василь Сухомлинський - педагог, гуманіст, науковець. Творчість В. Сухомлинського різнопланова і багатоаспектна, всі його роздуми торкаються проблем освіти, виховання, розвитку особистості дитини і педагога, батьківського всеобучу. Спадщину видатного педагога складають 48 книг, 500 наукових статей та понад 1500 казок і оповідань для дітей. 
Своєю творчістю він підніс українську педагогіку до світового рівня [7, с. 315].

Творчий спадок (педагогічні, публіцистичні та літературні праці) видатного українського педагога В. Сухомлинського і його практична діяльність (учительський та директорський досвід) збагатили педагогіку новими ідеями і думками. Його творчість із кожним роком привертає все більшу увагу вітчизняної і світової наукової й педагогічної громадськості, адже розроблена ним педагогічна система стала вагомим внеском у теорію і практику навчання і виховання, новим етапом у розвитку педагогічної думки. Багаторічний постійний інтерес до методичних ідей педагогічної спадщини В. Сухомлинського пов'язаний із іiі багатоаспектністю, різноплановістю, гуманістичною спрямованістю. Педагогічна творчість В. Сухомлинського багатогранна й невичерпно багата [1, с. 316].

Досвід вітчизняного педагога-гуманіста Василя Сухомлинського, методичні ідеї його педагогічної системи мають велике теоретичне і практичне значення особливо сьогодні, у період розбудови Нової української школи. Актуальними залишаються його ідеї, які відповідають загальноцивілізаційним тенденціям розвитку освіти щодо гуманізації освітнього процесу, методик навчання дітей, мотивів пізнавальної діяльності, особистісної орієнтації, дитиноцентризму, розвитку творчих сил кожної окремої дитини в умовах колективної співдружності, ідеї «радості пізнання», тобто емоційне сприйняття процесу навчання, виховання на цінностях, погляди на творчу професію вчителя і постійне вдосконаленні його майстерності, на контроль і керівництво освітнім процесом. Ми переконані, що ідеї В. О. Сухомлинського незаперечно утвердяться в педагогіці і філософії сучасної освіти, стануть основою реформаторських процесів освітньої сфери і сприятимуть подоланню викликів вітчизняної загальної середньої освіти.

У Концепції Нової української школи визначено формулу нової школи, яка поєднує 9 ключових компонентів: новий зміст освіти, заснований на формуванні компетентностей, необхідних для успішної самореалізації в суспільстві; умотивований учитель, який має свободу творчості й розвивається професійно; наскрізний процес виховання, який формує цінності; ефективне управління, що надасть школі реальну автономію; педагогіка, що грунтується на партнерстві між учнем, учителем і батьками; орієнтація на потреби учня в освітньому процесі, дитиноцентризм; нова структура школи, яка дозволяє добре засвоїти новий зміст і набути компетентності для життя; справедливий розподіл публічних коштів, який забезпечує рівний доступ усіх дітей до якісної освіти [17]. Зупинимося докладніше на окремих компонентах цієі формули, завдання яких найбільше суголосні з ідеями В. Сухомлинського.

Перший ключовий компонент формули Нової украӥнської иколи - новий зміст освіти. Оновлення змісту освіти, перехід на компетентнісне навчання зумовлені недосконалістю змісту шкільної освіти, недостатньою його орієнтованістю на формування здатності використовувати здобуті знання в житті і практичній діяльності. «Дитині недостатньо дати лише знання. Ще важливо навчити користуватися ними. Знання та вміння, взаємопов'язані $з$ ціннісними орієнтирами учня, формують його життєві компетентності, потрібні для успішної самореалізації у житті, навчанні та праці», - зазначено у формулі
Нової української школи [17]. Замість запам'ятовування фактів та визначень понять учні нової української школи набуватимуть компетентностей, формуватиметься ядро знань, на яке будуть накладатися вміння цими знаннями користуватися, цінності та навички, що знадобляться випускникам у професійному та особистому житті. Список компетентностей, яких набуватимуть учні, уже закріплено Законом України «Про освіту». Розпочато «перехід від школи, в якій тільки напихають знаннями та відтворюють їх, до школи компетентностей ..., формуються вміння вчитися протягом життя, громадянські компетентності, підприємливість, загальнокультурна грамотність, економічна й фінансова грамотність», - зазначає Л. Гриневич [2]. Отже, головним завданням сучасної школи стає не набуття знань, які дуже мінливі в сучасному світі, а навчання дітей отримані знання i навички застосовувати в житті. 3 огляду на це, зміст освіти повинен максимально відповідати потребам, інтересам та планам дитини на майбутнє.

Саме про це неодноразово писав у своїх працях В. Сухомлинський, розуміючи, що зміст освіти повинен містити людинознавчий компонент, особистісні технології людинотворення. У цьому сутність провідної ідеї теоретичного доробку вченого - розвиток особистості повинен відбуватися шляхом упровадження особистісного підходу до організації навчання і виховання. У книзі «Сто порад учителю» український педагог зазначає: «Однією з найважливіших особливостей творчості педагога є те, що об’єкт його праці - дитина - повсякчас змінюється, він завжди новий, сьогодні не той, що вчора. Наша праця - формування людини, і це покладає на нас особливу відповідальність, яку ні з чим не порівняєш» [14, с. 6].

Учителю сучасної школи для успішної роботи 3 дітьми такі настанови видатного педагога допоможуть закцентувати увагу не на змісті освіти як такому, а на дитині, якій цей зміст допоможе саморозвиватися, самовизначитися в житті, щоб бути самодостатньою та успішною. Педагогічна спадщина В. Сухомлинського (дидактичні ідеї, науково-популярні та художні твори) стане в нагоді й розробникам стандартів шкільної освіти, авторам програм та підручників, педагогам-практикам і сприятиме успішному становленню Нової української школи.

Другий ключовий компонент формули Нової украӥнської школи - педагогіка партнерства, в основі якої - «... спілкування, взаємодія та співпраця між учителем, учнем і батьками. Учні, батьки та вчителі, об'єднані спільними цілями та прагненнями, $\epsilon$ добровільними й зацікавленими однодумцями, рівноправними учасниками освітнього процесу, відповідальними за результат» [6]. Допомогти розкрити та розвинути здібності, таланти й можливості кожної дитини на основі партнерства між учителем, учнем і батьками - це місія Нової української школи... Серед основних принципів педагогіки партнерства: повага до особистості, доброзичливість і позитивне ставлення, довіра в стосунках, діалог - взаємодія - взаємоповага, розподілене лідерство, принципи соціального партнерства» [17].

На тому, що гармонійний, усебічний розвиток можливий лише за умови, коли школа і сім'я будуть діяти одностайно та стануть однодумцями у спільній роботі, наголошував у своїх працях і В. Сухомлинський, зокрема й на важливості залучення родини до побудови освітньо-професійної траєкторії дитини. 
Він розумів: коли школа, громада, батьки виступають у єдності, це вчить дітей мудрості, гармонії, вимогливості. Гармонійний, усебічний розвиток можливий лише там, де два вихователі - школа і сім'я - не тільки діють одностайно, ставлячи перед дітьми ті самі вимоги, а є однодумцями, поділяють ті самі переконання, завжди виходячи 3 тих самих принципів, не допускають ніколи розходження ні в меті, ні в процеci, ні в засобах виховання» $[14$, с. 55].

Неабияку увагу вчений приділяв співдружності родини та школи, педагогічній освіті батьків. Батьківська педагогіка, тобто елементарне коло знань матері та батька - це фундамент, основа всієї педагогічної теорії й практики» [14, с. 24]. У статті «Слово до батьків» він пропагував ідею повернення педагогічної відповідальності в родину [9]. «На моє глибоке переконання, - писав Василь Олександрович, - педагогіка повинна стати наукою для всіх: і для вчителів, і для батьків» [11, с. 46]. Свої ідеї щодо педагогіки партнерства, висловлюючись сучасною термінологі-

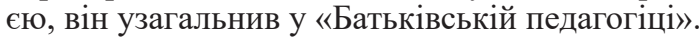

Коли сьогодні чуємо, що учень не мотивований до навчання, радимо звертатися до настанов В. Сухомлинського, зокрема до спільного вирішення проблеми - разом із батьками, школою та учнем. Співпраця між усіма учасниками освітнього процесу - наріжний камінь, який допоможе досягти всіх інших результатів, адже тільки так можливо зробити українську школу відкритою, інноваційною та цікавою.

Третій ключовий компонент формули Нової украӥнськоӥ иколи - умотивований учитель. Без учителя, який має свободу творчості й розвивається професійно, який готовий стати агентом змін, партнером, фасилітатором, коучем, модератором, який взаємодіятиме з батьками та учнями для максимального розкриття дитячих здібностей, говорити про успіхи реформи не доводиться. Про нову роль учителя в умовах Нової української школи зазначає О. I. Ляшенко: «Автономія закладу освіти надає вчителеві академічну свободу у виборі методів і технологій навчання, програм, підручників і навчальних посібників, побудови авторських освітніх програм. Учитель із транслятора і джерела знань має стати наставником і помічником учня у виборі ним власної освітньої траєкторії, допомогти йому виявити і розвинути свої таланти і здібності, визначитися в майбутньому життєвому шляху. Для цього він повинен не лише володіти сучасними педагогічними технологіями, умінням управляти індивідуалізованим освітнім процесом, але й бути обізнаним із різними психологічними теоріями індивідуальної і групової роботи з учнями, мати відповідні навички впливу на дитину» [3, с. 42]

Доцільними і педагогічно виправданими сьогодні $\epsilon$ настанови В. Сухомлинського про те, що «школа це насамперед учитель. Особистість учителя - наріжний камінь виховання» [15]. За його переконанням, тільки творча особистість учителя може виховати творчого учня. Від учителя, від його вміння, майстерності, мудрості залежить життя дитини, здоров'я, розум, характер, воля, становлення як громадянина, патріота, їі місце і роль у житті.

У світлі поставлених перед сучасним учителем завдань особливої актуальності для його професійного становлення й розвитку набувають такі праці Василя Сухомлинського, як «Педагогічна культура», «Павлиська середня школа», «Як виховати справжню людину», «Розмова 3 молодим директором школи»,
«Сто порад учителеві», «Серце віддаю дітям», «Майстерність», «Високе покликання педагога», «Учитель і діти», «Суспільство і вчитель».

На думку Василя Олександровича, вчитель повинен максимально наближувати освітній процес до життєвих реалій. Недостатньо знати свій предмет. Набагато важливіше - вміти проникати до дитячого розуму, думок, почуттів дітей. Педагог писав, що перш ніж учити дітей запам'ятовувати, їх потрібно вчити думати, мислити, аналізувати факти і явища навколишнього світу. Якщо повторення - мати навчання, то спостереження - мати обдумування і запам'ятовування знань [8]. Ці думки вченого сьогодні актуалізовані в технології критичного мислення, покликаної розвивати в учнів навички критичного мислення, вміння вирішувати неординарні практичні завдання. Оволодіння вчителем технологією навчання, орієнтованого на розвиток критичного мислення, $\epsilon$ нагальною методичною проблемою сучасної освіти, оскільки навички критичного мислення стануть запорукою успіху в інформаційному суспільстві, де саме розумові здібності людини, а не природні ресурси і капітал, визначатимуть першорядну роль.

Суголосними ідеям Нової української школи $є$ слова В. Сухомлинського про вчителя. Великий педагог застерігав, що вчителю мало знати предмет, він має бути майстром, психологом, дослідником: «Учителеві треба знати значно більше ніж вимагає програма» [10, с. 55]; «Знати в сто разів більше ніж дає учням на уроках», «Без твердого психологічного грунту нема педагогічної культури» [10]; «Кожний рік повинен збагачувати технічну лабораторію педагогічної праці» [8]. Поєднання практики з елементами наукового дослідження Василь Олександрович вважав вищим етапом педагогічної творчості, адже «стає майстром педагогічної праці звичайно той, хто відчув себе дослідником» [9, с. 471]; «постійне поповнення наукових знань дуже важлива умова багатого інтелектуального життя учнівського колективу, передумова високого наукового рівня викладання основ наук» [9, с. 220].

Беручи до уваги настанови великого педагога, вчитель Нової української школи має усвідомити, що без сучасних педагогічних технологій (особистісно зорієнтоване, розвивальне, проектне, інтерактивне, модульне навчання, ігрові, комп'ютерні, тестові технології, технологія інтенсивного навчання, критичного мислення та ін.), арсеналу методів навчання (методи проектів, портфоліо, частково-пошукові та дослідницькі тощо) неможливий модернізаційний освітній поступ.

Незамінним інструментом впливу на душу дитини Василь Олександрович уважав учительське слово, мистецтво говорити, вміння звертатися до людського серця. «В руках вихователя - слово, - стверджує Василь Олександрович, - такий же могутній засіб, як музичний інструмент у руках музиканта, як фарби в руках живописця, як різець і мармур у руках скульптоpa.... Слово - це ніби той місток, через який наука виховання переходить у мистецтво, майстерність» [16]. Особливо це важливо для вчителів нинішньої початкової школи (1-2 класи), коли слово вчителя має не сполохати трепетну дитячу душу, а вселити віру, що дитині тут раді, що їй тут буде комфортно, затишно і цікаво. «Слово - найтонше доторкання до серця; воно може стати і ніжною запашною квіткою, і живою водою, що повертає віру в добро, і гострим ножем, 
і розжареним залізом, і брудом... Одна з граней педагогічної мудрості полягає в тому, щоб учити людину говорити, і мовчати. Виховувати слово так, щоб воно було сміливим і скромним, нестримним і сором'язливим, безстрашним і обережним» [13, с. 327]. Допомогти вчителям в усвідомленні сутності цієї настанови допоможуть праці «Слово рідної мови» та «Джерело невмирущої криниці».

Цінні поради залишив Василь Олександрович щодо фахового росту вчителя. «Треба будувати, - наголошував він, - міцну інтелектуальну основу для педагогічної майстерності» [9]. Такою основою він вважав систему методичної роботи. Структура, форми, зміст методичної роботи в Павлиській школі були спрямовані на поглиблення професійної компетентності, ознайомлення з науковими досягненнями, оволодіння новими технологіями, методами навчання та виховання. Формування педагогічної майстерності, педагогічної творчості, на його думку, слід розпочинати в педагогічних закладах і продовжувати в школі в процесі ознайомлення 3 роботою педагогів-майстрів шляхом осмислення їх досвіду, творчого використання колективної творчості колег. У бесіді з молодим директором школи «Основні проблеми творчої праці педагога» він наголошує на відповідальності керівника за розвиток творчості колективу і кожного вчителя: «Дух часу, взаємини між людьми - усе це залежить від того, які ми з вами, від того, яка школа, що їй народ ввіряє своє майбутнє, від того, яке керівництво школою» [9].

Найбільш поширеною груповою формою науково-методичної роботи $\epsilon$, на його думку, методичні об'єднання, кафедри. На їх засіданнях він пропонував обговорювати питання підвищення рівня освітньої роботи та якості знань учнів, методики викладання, впровадження педагогічного досвіду і досягнення педагогічної науки, упровадження інновацій, програми, організації та проведення позакласної роботи тощо. Великий педагог був переконаний, що саме системна методична робота забезпечує належний професійний розвиток учителя. Звучить актуально, особливо якщо брати до уваги непоодинокі факти нехтування методичною роботою.

Актуальною залишається ідея педагога-новатора щодо важливості самоосвіти вчителя: «Знання, добуті самоосвітою, дуже міцно зберігаються в пам'яті... У процесі самоосвіти формуються індивідуальні риси особистості, виробляється індивідуальний стиль розумової праці» [14].

Особистісно орієнтований, діяльнісний і компетентнісний підходи, покладені в основу реформування середньої освіти, потребують відповідної готовності і здатності не лише вчителя, а й керівника закладу освіти. Про роль директора у підготовці вчителя у свій час багато говорив і писав Василь Олександрович. «Якщо ви хочете духом творчого пошуку збагатити життя колективу, будьте самі шукачем i дослідником, - радив В. О. Сухомлинський молодим директорам шкіл, - не буде вогника у вас - вам ніколи не запалити його в інших» [9].

Четвертий ключовий компонент формули Нової української иколи - автономія иколи. Уся педагогічна діяльність В. Сухомлинського як учителя й директора Павлиської школи грунтується на ідеях, які стосуються й питання автономії школи, зокрема організаційної та кадрової. Він утілив у практику школи принципи довіри (мінімум контролю); запровадив громадське самоврядування, за яким в управлінні школою брали участь учні, батьки та вчителі; започаткував «педагогіку успіху» як механізм подальшого розвитку особистості учня; мав власне бачення щодо виховного процесу, виховання дитини, де знанням відводилася роль засобу для досягнення мети; надавав вагомого значення ситуації успіху в розвитку дитини, іiі самостановленні та вірі в свої сили, що лягло в основу сучасної «Я-концепції»; втілював підхід до дитини як до неповторної людської індивідуальності, наголошуючи, що кожна дитина розумна і талановита по-своєму, що серед дітей немає жодної нездібної; надавав неабиякого значення формуванню творчої активності дитини, що сьогодні $є$ основою компетентнісного навчання; реалізовував принцип «виховання без покарань», поважаючи при цьому «дитяче незнання».

Наступний важсливий ключовий компонент формули Нової украӥнської иколи - орієнтація на учня. Концепція «Нова українська школи» пропонує особистісно орієнтовану модель освіти, яка максимально враховуватиме права дитини, ії здібності, потреби та інтереси, на практиці реалізуючи принцип дитиноцентризму... Освітню діяльність буде організовано з урахуванням розвитку навичок XXI століття ... Нова українська школа буде розкривати потенціал кожної дитини [17].

Потребу орієнтації на кожну дитину гостро відчував і переконливо відстоював у своїх працях Василь Сухомлинський, незважаючи на властиву радянській педагогіці апологетику колективізму. Беручи до уваги цю настанову, ми не повинні творити в школі культ оцінки, не заповнювати дитячі голови знаннями, а навчити, як цими знаннями користуватися, тобто - перейти до школи компетентностей.

«Ми переконалися, - писав В. Сухомлинський, що оволодіння знаннями в початковій школі без заучування - важлива передумова подальшого розвитку вихованців...» [8]. Педагог приділяв значну увагу вивченню та врахуванню вікових особливостей учнів, наголошував на дотриманні вчителем індивідуального темпу розвитку кожної дитини, про що писав у багатьох працях.

Можливо, ідеї особистісно орієнтованого підходу у навчанні та вихованні не були глибоко і всесторонньо обгрунтовані в творах Василя Олександровича, проте вони успішно реалізувалися на практиці в його школі. Саме його теоретико-методологічні основи особистісно зорієнтованого підходу в навчанні та вихованні закладені в Концепцію Нової української школи (виявлення індивідуальних пізнавальних здібностей, опертя на життєвий і практичний досвід учнів, допомога кожному пізнати себе, самовизначитися і самореалізуватися, максимальне врахування прав дитини) і використовуються сьогодні на практиці в освітньому процесі закладів освіти.

В. О. Сухомлинський уважав дуже важливим, щоб у світ суспільних відносин дитину вводили через світ природи. «Школа під голубим небом», уроки на природі, перші дитячі істини з оточуючого світу, через світ природи у світ суспільних відносин - ці ідеї видатного вченого сьогодні розвиваються, поглиблюються і переосмислюються для активного впровадження педагогами Нової української школи.

Отже, орієнтація на потреби кожної конкретної дитини має стати основною складовою ідеології сучасної школи. 
Ще один ключовий компонент формули Новоі української школи - сучасне освітнє середовище. Формування нового освітнього середовища - це не просто вимога Нової української школи щодо оновлення матеріально-технічної бази школи і класу, це зміна ставлення до дитини, намагання знайти оптимальний спосіб для іiі ефективного навчання, виховання і розвитку. Це створення багатофункціональних гнучких просторів для різноманітних форм освітньої діяльності, забезпечення сприятливої емоційної атмосфери, мотивації та налаштування на продуктивну працю. Реалізація середовищного підходу сприяє організації освітнього процесу відповідно до вікових та індивідуальних особливостей дитини.

Питання освітнього середовища було близьким i В. Сухомлинському. Створення комфортного середовища для навчання він розглядав як комплекс взаємопов'язаних компонентів, відносив до нього і найближчий до дитини світ - школу та клас, і віддалений у часі і просторі - село, місто, країну, природу тощо. Особливого значення надавав Василь Сухомлинський природі, для нього «... кожна мандрівка в природу - урок мислення, урок розвитку розуму». Гарна настанова, шкода, що рідко використовується сучасними педагогами 3 огляду на об'єктивні умови та суб'єктивізм окремих педагогів.

Заключний ключовий компонент формули Нової украӥнської школи - виховання на цінностях. Нова українська школа буде формувати ціннісні ставлення і судження, які слугують базою для щасливого особистого життя та успішної взаємодії з суспільством... Виховний процес буде невід'ємною складовою всього освітнього процесу й орієнтуватиметься на загальнолюдські цінності... Нова школа буде плекати українську ідентичність... Виховання здійснюватиметься через наскрізний досвід [17].

Питання виховання було наріжним каменем педагогічної системи В. Сухомлинського. Пріоритетним у виховній роботі педагог уважав громадянське виховання, формування громадянина, «піклування про громадянську лінію всього процесу виховання» [12]. «Народження громадянина», «Батьківська педагогіка», «Як виховати справжню людину», «Хрестоматія 3 етики» - ці та інші праці мають бути настільними сьогодні як для вчителя, так і для керівника закладу.

Василь Сухомлинський зазначав, що саме через громадянську активність, безпосередню участь у громадських справах і можна виховати справжніх патріотів: «Якщо в дитинстві й отроцтві людина піклувалася про свої інтереси, якщо спільне стало для неї глибоко особистим, вона у зрілі роки стане справжнім патріотом» [4, с. 16].

Велику небезпеку вбачав В. Сухомлинський у тому, що освіта здебільшого орієнтувалася на розвиток інтелекту школяра, при цьому чуттєвій сфері не приділялася належна увага. Його ідея культивування сердечності, навпаки, полягала у формуванні співчуття, чуйності, піклування, доброти до всього прекрасного, і насамперед до людини, тобто у формуванні духовно-моральних цінностей. Для В. Сухомлинського це було принципово важливим, тому що виховання гуманізму, людяності здійснюється через творення людям добра.

Висновки. Педагогічна спадщина В. Сухомлинського $є$ невичерпним джерелом ідей, тому не втрачає значущості для сучасної педагогічної науки i практики. Його багатоаспектні науково-педагогічні надбання торкаються найважливіших проблем (змісту освіти й виховання, мотивації й методики навчання дітей, контролю і керівництва освітнім процесом, підготовки вчителя та багатьох інших) і сприяють у вирішенні питань сучасної освіти. Ідеї великого педагога допомагають краще зрозуміти дитину та вдосконалювати педагогічну техніку.

Унікальність педагогічного досвіду Василя Олександровича, творчий підхід до теорії і практики навчання й виховання, особистісної орієнтації навчання, ідеї позитивної «Я-концепції» $\epsilon$ не лише цінним внеском у вітчизняну та світову скарбницю педагогічної думки, вони стають фундаментом сучасної освітньої системи. Через поєднання теоретичних узагальнень iз багатим практичним досвідом педагогічна спадщина Василя Сухомлинського й досі не втрачає своєї актуальності та значущості.

Для ефективної реалізації положень нового Закону України «Про освіту», Концепції «Нова українська школа», успішного реформування української школи доцільно ще раз перечитати праці великого педагога й отримати відповіді на актуальні освітні питання. Варто бути лише хорошими читачами і мати бажання впроваджувати дані нам поради в життя. I тоді «школа радості» стане не просто казкою, а реальністю.

\section{СПИСОК ВИКОРИСТАНОЇ ЛІТЕРАТУРИ}

1. Герасимова Г. П. Сухомлинський Василь Олександрович : [біогр. нарис] / Г. П. Герасимова // Енциклопедія історії України : у 10 т. Т. 9. Прил - С / НАН України, Інститут історії України ; редкол. : В. А. Смолій (голова) [та ін.]. - К. : Наук. думка, 2012. C. 316.

2. Гриневич Л. М. Від школи, де накачують знаннями, ми переходимо до школи компетентностей [Електронний ресурс] / Л. М. Гриневич. URL: https://dt.ua/EDUCATION/liliya-grinevich-perehodimovid-shkoli-v-yakiy-tilki-napihayut-znannyami-tavidtvoryuyut-yih-do-shkoli-kompetentnostey-252819_. html (дата звернення: 20.08.2019).

3. Ляшенко О. І. Пріоритети розвитку української школи в умовах реформування освіти [Електронний pecypc] / О. I. Ляшенко // Збірник наукових праць Кам'янець-Подільського національного університету ім. І. Огієнка. - 2016. - Вип. 22. - С. 42. - (Серія «Педагогічна»). URL: http://nbuv.gov.ua/UJRN/znpkp_ ped_2016_22_13] (дата звернення: 21.08.2019).

4. Момотюк Л. Б. Громадянське виховання молодших школярів : дис. ... канд. пед. наук : 13.00.07 / Л. Б. Момотюк. - Рівне, 2007. - С. 16.

5. Національна доповідь про стан і перспективи розвитку освіти в Україні / Нац. акад. пед. наук України ; за заг. ред. В. Г. Кременя. - К. : Педагогічна думка, 2016. - 448 с.

6. Нова українська школа (оновлена концепція) [Електронний ресурc]. URL: https://mon.gov. $\mathrm{ua} / \mathrm{storage} / \mathrm{app} / \mathrm{media} / \mathrm{zagalna} \% 20$ serednya/novaukrainska-shkola-compressed.pdf (дата звернення: 20.08.2019).

7. Скільський Д. М. Історія української педагогіки. Ілюстрований навчальний посібник / Д. М. Скільський. - Тернопіль : Навчальна книга - Богдан, 2012. C. 315 .

8. Сухомлинський В. О. Вибрані твори : у 5 т. [Текст] / В. О. Сухомлинський. - Київ : Рад. школа, 1976. - T. 2. -679 c. 
9. Сухомлинський В. О. Вибрані твори : в 5 т. [Текст] / В. О. Сухомлинський. - Київ : Рад. школа, 1997. - T. 4. -637 c.

10. Сухомлинський В. О. Вибрані твори : в 5 т. [Текст] / В. О. Сухомлинський. - Київ : Рад. школа, 1976 - 1977. - T. 4. - 419 с.

11. Сухомлинський В. О. Проблеми виховання всебічно розвиненої особистості / В. О. Сухомлинський // Вибр. твори : в 5 т. - К., 1976. - Т. 1. - С. 46.

12. Сухомлинський В. О. Розмова 3 молодим директором школи / В. О. Сухомлинський // Вибр. твори : в 5 т. - К. : Рад. школа, 1997. - Т. 4. - С. 554.

13. Сухомлинський В. О. Слово вчителя в моральному вихованні / В. О. Сухомлинський // Вибр. твори : в 5 т. - К. : Рад. школа, 1977. - Т. 5. - С. 321-330.
14. Сухомлинський В. О. Сто порад учителеві / В. О. Сухомлинський // Вибр. твори : в 5 т. - М. : Педагогика, 1979. - Т. 4. - С. 6.

15. Сухомлинський В. О. Як виховувати справжню людину / В. О. Сухомлинський // Вибр. твори : в 5 т. - К. : Рад. школа, 1977. - Т. 2. - С. 158-199.

16. Сухомлинський В. О. Вибр. твори : в 5 т. Т. 3. Серце віддаю дітям. Народження громадянина. Листи до сина / В. О. Сухомлинський. - К. : Рад. школа, 1977. - c. 160.

17. Формула Нової української школи [Електронний ресурс]. URL: https://nus.org.ua/about/formula/ (дата звернення: 21.08.2019).

Дата надходження до редакиії: 26.08.2019 p.

\section{СПАДЩИНА В. О. СУХОМЛИНСЬКОГО У ПІСЛЯДИПЛОМНІЙ ОСВІТІ ВЧИТЕЛЯ НОВОЇ УКРАЇНСЬКОЇ ШКОЛИ НА ВОЛИНІ}

\begin{abstract}
У статті розглянуто використання спадщиини всесвітньо відомого педагога-новатора В. О. Сухомлинського в системі післядипломного підвищення кваліфікачї̈ педагогічних працівників у контексті ідей Нової украӥнської школи.

Ключові слова: Нова украӥнська школа, післядипломна освіта, форми $і$ методи навчання, компетентність, компоненти, освітній процес, дослідження, вчитель, nатріот.
\end{abstract}

В статье рассмотрено использование наследия всемирно известного педагога-новатора В. А. Сухомлинского в системе последипломного повышения квалификации педагогических работников в контексте идей Новой украинской школьл.

Ключевые слова: Новая украинская школа, последипломное образование, формы и методы обучения, компетентность, компоненты, образовательный проиесс, исследование, учитель, патриот.

The article deals with the creative heritage of the world-famous teacher-innovator $V$. O. Sukhomlynskyi in the conditions of Ukrainian education modernization, especially in the regional system of teachers' postgraduate professional development, according to the New Ukrainian School Concept. His ideas of the educational process humanization, the promotion and preservation of children's health, the development of students' abilities and talents and the formation of teachers' skills are relevant and systematically used by educational authorities, scientific and pedagogical staff, methodological services in Volyn Region. The teacher-innovator heritage is introduced for consideration at the meetings of city and district departments of education, councils of methodological services, pedagogical councils of educational institutions and reflected in school principles', methodologists', teachers 'plans of work.

Having started in Volyn In-Service Teachers' Training Institute in 1994, All-Ukrainian Pedagogical Readings in honour of Vasyl Sukhomlynskyi are annually organized in one of the regions of Ukraine. Under the organizational participation of Volyn Regional Institute of Postgraduate Pedagogical Education staff, different scientific and methodological events, such as conferences, seminars, readings, round table discussions and more were held in the region to celebrate the 100th anniversary of $V$. O. Sukhomlynskyi's birth.

Various forms of studying and technological application of $V$. O. Sukhomlynskyi's innovative ideas in the educational space of Volyn region for realization of the tasks of the New Ukrainian School concept in accordance with the requirements of state and sectoral legislation are analyzed. The training at the Institute is practically oriented on the upgrading of teachers' knowledge and skills in the pedagogical innovations, project technologies, digital educational resources, research methods and upbringing of patriots, that is, the formation of educational process participants' competences.

Key words: New Ukrainian School, postgraduate education, educational process, teacher, forms and methods of teaching, competence, research, patriot. 